\title{
How Basic Immunological Principles May Instruct the Design of a Successful HIV-Type 1 Vaccine
}

\author{
Karen S. Slobod ${ }^{1}$ and Julia L. Hurwitz ${ }^{2}$
}

\begin{abstract}
This article is dedicated to Dr. Peter Doherty. While Peter continues to make groundbreaking discoveries in the field of immunology, he also provides outstanding scientific mentorship to his trainees. Here we contemplate our past training with Peter, Peter's teachings of basic immunological principles, and how basic principles may instruct the design of a successful human immunodeficiency virus-type 1 vaccine.
\end{abstract}

Keywords: mentor, infectious diseases, immune response, vaccine development, superinfection

\section{Training with Peter Doherty}

W E WERE TRAINED as fellows in the laboratory of Dr. Peter Doherty where we were taught the basic concepts of immunology. Peter described how lymphocytes recognize and then eradicate invading viruses. While teaching and engaging trainees in his ongoing projects, Peter also encouraged scientific independence. Unlike many mentors who focus primarily on their own ideas, Peter encouraged young scientists to formulate new hypotheses. He supported scientific freedom both within his laboratory and for trainees who graduated from his laboratory to advance their independent careers.

In the mid-1990s, after we had graduated from Peter's laboratory and had taken new positions in Peter's Immunology Department at St. Jude Children's Research Hospital (St. Jude), we initiated development of a clinicalgrade vaccine. We were soon meeting with Food and Drug Administration (FDA) officials and learning Good Manufacturing Practices (GMPs) required for the development of clinical biologicals. These steps paved the way for the preparation of clinical vaccine material and the conduct of a first phase I clinical vaccine study at St. Jude. Today, the Children's GMP LLC on the St. Jude campus produces dozens of products for clinical applications.

It was while we were advancing our first vaccine candidates in 1996 that Peter and Dr. Rolf Zinkernagel received the Nobel Prize in Physiology or Medicine for their groundbreaking discovery of major histocompatibility complex
(MHC) restriction. In the 1970s, Peter and Rolf found that immune $\mathrm{T}$ cells only recognized infected target cells when the $\mathrm{T}$ cell and target cell shared MHC (14,54-57). This discovery drove further research into $\mathrm{T}$ cell receptor, viral peptide, and MHC interactions (20) and has since served as the foundation for decades of basic and clinical advances in vaccine development and $\mathrm{T}$ cell immunotherapies. Peter accepted the Nobel Prize with humility. Even today, when young scientists meet Peter, they are impressed with his humility and willingness to stop and discuss science. Peter is never too busy to listen and provide advice. In sum, Peter taught us and teaches us how to perform research, how to enjoy research, how to share research, and how basic immunological principles can translate to extraordinary improvements in human health.

\section{Basic Immunology Concepts and Vaccine Development}

Evolution has armed mammals with an impressive means of immune protection. The sophisticated joining of immunoglobulin or T cell receptor variable, diversity, and joining (V-D-J) gene segments in developing B cells and T cells provides humans with as many as $10^{20}$ different receptors [one model predicts that the receptor number is $>10^{60}$ ] $(13,28,32)$. Each lymphocyte bears a different receptor and each receptor has a different antigenic specificity. Immune receptors bind their targets (free antigen for B cells and peptide-MHC complexes for T cells) using highly specific

\footnotetext{
${ }^{1}$ Cambridge Consulting, Cambridge, Massachusetts.

${ }^{2}$ Department of Infectious Diseases, St. Jude Children's Research Hospital, Memphis, Tennessee.

(c) Karen S. Slobod and Julia L. Hurwitz, 2020; Published by Mary Ann Liebert, Inc. This Open Access article is distributed under the terms of the Creative Commons Attribution Noncommercial License (http://creativecommons.org/licenses/by-nc/4.0/) which permits any noncommercial use, distribution, and reproduction in any medium, provided the original author(s) and the source are cited.
} 
"lock-and-key" (target-to-receptor) interactions. Accordingly, the enormous diversity of unique immune cells/receptors has the potential to protect humans against virtually any pathogen in nature.

Vaccine developers may take advantage of diverse B and $\mathrm{T}$ cell receptor repertoires by designing look-a-like vaccines. When a vaccine "looks like" its target pathogen (i.e., carries antigens that are structurally matched), the vaccine will safely activate (by "lock-and-key" interactions with lymphocyte receptors) the B cells and T cells that can crossreact with the pathogen. These lymphocytes then amplify and serve as an army, ready to tackle pathogen when an exposure occurs at a later date. Lymphocyte activation before pathogen exposure is essential, particularly for persistent viruses such as human immunodeficiency virus-type 1 (HIV-1), which in the absence of primed defenses can establish permanent residence in immune-privileged sites.

\section{HIV-1 Vaccine Development}

HIV-1 is a formidable human pathogen. In part, this is because HIV-1's attachment envelope protein (Env) can vary [although Env diversity is limited by its requirement to bind conserved CD4 (26) and co-receptor molecules]. HIV1 is not the first diverse pathogen to pose a challenge to vaccine development; in other fields, vaccines against diverse pathogens have already been designed and licensed. In the 1950s, Jonas Salk produced a successful polio vaccine by combining representatives of three circulating poliovirus serotypes into a cocktail $(4-6,22,24)$. Streptococcus pneumoniae vaccines have similarly proven effective, because they are cocktails that represent diverse serotypes. Cocktail vaccines for $S$. pneumoniae were being formulated as early as 1945 and resulted in a vaccine, still used today, comprising 23 purified capsular polysaccharides for representation of 23 different serotypes $(2,50)$. When pneumococcus conjugate vaccines were first developed, only seven serotypes of pneumococcus were included (Prevnar), but breakthrough infections occurred and vaccine valency was accordingly increased $(19,21,47)$. The current conjugate vaccine formulation (Prevnar 13) includes 13 serotypes (1), and new vaccine candidates comprising even more distinct serotypes are being developed. It should be noted that the public health benefits conferred even by the smallest vaccine cocktail formulations have been immeasurable.

Adding to lessons from other vaccine fields, insight into successful HIV-1 vaccine development can be gained by analyses of natural virus infections. Studies have shown that animals previously exposed to HIV-1 (or simian immunodeficiency virus [SIV] or chimeric HIV-SIV [SHIV] in nonhuman primate models) are often protected from superinfection $(9,10,12,15,33,37,43,45)$. Furthermore, the passive transfer of sera from an infected animal to a naive animal can be protective $(27,34,46)$.

The immunity against exogenous virus that is conferred by infection is a consequence of a complex interplay between endogenous virus and the immune system. When a naive individual is naturally infected with HIV-1, the founder virus is limited in diversity and the consequent immune response is similarly limited (49). Virus is not cleared, but it is instead sequestered in privileged sites. Virus then mutates, generating new Env structures that can support HIV-1 infection and can escape the contemporaneous systemic immune response $(31,49)$. When new virus variants circulate, they activate new lymphocytes, increasing the breadth of the immune response. Activated B cells also experience somatic mutation, after which cells that bear receptors with improved affinity and avidity toward viral antigens are amplified (17). After several rounds of virus escape and lymphocyte activation, immune breadth is sufficient to recognize diverse HIV-1 and thereby protect against virus infections from an exogenous source $(29,35,49)$. Vaccines designed to recapitulate the Env diversity that is introduced by a natural virus infection are likely to prove successful (29).

Yet another lesson informing HIV-1 vaccine development can be gleaned from the RV144 HIV-1 vaccine study (30). Although this clinical trial suggested a vaccine efficacy of only $\sim 30 \%$ (in a modified intention-to-treat analysis), it is noteworthy that the vaccine included only three different Env. One genetically engineered Env was expressed with other HIV-1 proteins by recombinant canarypox and two Env were included in a protein boost (51). Trial results were disappointing, but they pointed to the potential efficacy that could be afforded by a larger vaccine cocktail (as was observed in the pneumococcal vaccine field).

\section{Creating an HIV-1 Cocktail Vaccine}

Successful multivalent or "cocktail" vaccines (such as those tested in the 1940s and 1950s) were designed to represent antigenically distinct target pathogens by mapping (cartography) studies that tested antigen-antibody interactions (4-6,24,41). Similar antigen-antibody mapping studies have been initiated in the HIV-1 vaccine field by using virus isolates/proteins and sera/antibodies $(3,23,25,38,58)$. These have defined antigenic clusters, but they have not yet been used to advance a vaccine to licensure.

Results from antigen-antibody mapping studies emphasize that the virus's clade (sequence) and country of origin do not always predict antigenicity $(3,23,40,48)$. Rather, some viruses from two different clades and countries share antigenicity, whereas some viruses from the same clade and country do not. This result is expected, because B cell and $\mathrm{T}$ cell epitopes are influenced by structure (including threedimensional and four-dimensional protein configurations), not just sequence, and because structure can be altered by one or a few amino acid changes within or distant from a target epitope $(7,8,11,16,36,44)$.

Cartography studies in the HIV-1 field could be easily expanded and fine-tuned using high-throughput antigenantibody assays to create vaccine cocktails representing most functional Env antigens. The immune system naturally responds to a plethora of diverse antigens in the human environment and can also respond to large multicomponent vaccines (e.g., the pneumococcus vaccines described earlier or much larger vaccine libraries) $(18,39,42,52,53)$.

Presumably large HIV-1 cocktail vaccines will eventually be developed, shown to induce protective immunity, and licensed. Inferring from previous successful vaccines such as Prevnar, it is possible that HIV-1 vaccine development will be iterative-advancing in vaccine efficacy with each subsequent iteration.

The multi-Env cocktail vaccine approach is slowly gaining momentum in the HIV-1 vaccine field. Goals are to 
recruit an array of lymphocytes with diverse receptors and to promote somatic mutations to improve receptor affinity, avidity, and breadth (17). These outcomes may together, ultimately, protect humans from a deadly disease.

\section{Acknowledgment}

We thank Dr. David Finklestein for assistance with an evaluation of mapping data.

\section{Author Disclosure Statement}

No competing financial interests exist.

\section{Funding Information}

This study was supported by ALSAC.

\section{References}

1. Andrews NJ, Waight PA, Burbidge P, et al. Serotypespecific effectiveness and correlates of protection for the 13-valent pneumococcal conjugate vaccine: a postlicensure indirect cohort study. Lancet Infect Dis 2014;14:839-846.

2. Austrian R, Douglas RM, Schiffman G, et al. Prevention of pneumococcal pneumonia by vaccination. Trans Assoc Am Physicians 1976;89:184-194.

3. Binley JM, Wrin T, Korber B, et al. Comprehensive crossclade neutralization analysis of a panel of anti-human immunodeficiency virus type 1 monoclonal antibodies. J Virol 2004;78:13232-13252.

4. Bodian D. Differentiation of types of poliomyelitis viruses; reinfection experiments in monkeys (second attacks). Am J Hyg 1949;49:200-223.

5. Bodian D. Neutralization of three immunological types of poliomyelitis virus by human gamma globulin. Proc Soc Exp Biol Med 1949;72:259-261.

6. Bodian D, Morgan IM, and Howe HA. Differentiation of types of poliomyelitis viruses; the grouping of 14 strains into three basic immunological types. Am J Hyg 1949;49:234-245.

7. Brown SA, Slobod KS, Surman S, et al. Individual HIV type 1 envelope-specific $\mathrm{T}$ cell responses and epitopes do not segregate by virus subtype. AIDS Res Hum Retroviruses 2006;22:188-194.

8. Caton AJ, Brownlee GG, Yewdell JW, et al. The antigenic structure of the influenza virus A/PR/8/34 hemagglutinin (H1 subtype). Cell 1982;31:417-427.

9. Chakraborty B, Valer L, De MC, et al. Failure to detect human immunodeficiency virus type 1 superinfection in 28 HIV-seroconcordant individuals with high risk of reexposure to the virus. AIDS Res Hum Retroviruses 2004; 20:1026-1031.

10. Cranage MP, Whatmore AM, Sharpe SA, et al. Macaques infected with live attenuated SIVmac are protected against superinfection via the rectal mucosa. Virology 1997;229: 143-154.

11. D'Costa S, Slobod KS, Webster RG, et al. Structural features of HIV envelope defined by antibody escape mutant analysis. Aids Res Hum Retroviruses 2001;17:1205-1209.

12. Daniel MD, Kirchhoff F, Czajak SC, et al. Protective effects of a live attenuated SIV vaccine with a deletion in the nef gene. Science 1992;258:1938-1941.

13. Dash P, Fiore-Gartland AJ, Hertz T, et al. Quantifiable predictive features define epitope-specific $\mathrm{T}$ cell receptor repertoires. Nature 2017;547:89-93.
14. Doherty PC, and Zinkernagel RM. H-2 compatibility is required for T-cell-mediated lysis of target cells infected with lymphocytic choriomeningitis virus. J Exp Med 1975; 141:502-507.

15. Enose Y, Ui M, Miyake A, et al. Protection by intranasal immunization of a nef-deleted, nonpathogenic SHIV against intravaginal challenge with a heterologous pathogenic SHIV. Virology 2002;298:306-316.

16. Gerhard W, Yewdell J, Frankel ME, et al. Antigenic structure of influenza virus haemagglutinin defined by hybridoma antibodies. Nature 1981;290:713-717.

17. Hurwitz JL, and Bonsignori M. Multi-envelope HIV-1 vaccine development: two targeted immune pathways, one desired protective outcome. Viral Immunol 2018;31:124132.

18. Jones BG, Sealy RE, Zhan X, et al. UV-inactivated vaccinia virus (VV) in a multi-envelope DNA-VV-protein (DVP) HIV-1 vaccine protects macaques from lethal challenge with heterologous SHIV. Vaccine 2012;30:31883195.

19. Kim NH, Lee J, Lee SJ, et al. Immunogenicity and safety of pneumococcal 7-valent conjugate vaccine (diphtheria CRM(197) protein conjugate; Prevenar) in Korean infants: differences that are found in Asian children. Vaccine 2007; 25:7858-7865.

20. La Gruta NL, Gras S, Daley SR, et al. Understanding the drivers of MHC restriction of $\mathrm{T}$ cell receptors. Nat Rev Immunol 2018;18:467-478.

21. Lipsitch M, O’Neill K, Cordy D, et al. Strain characteristics of Streptococcus pneumoniae carriage and invasive disease isolates during a cluster-randomized clinical trial of the 7valent pneumococcal conjugate vaccine. J Infect Dis 2007; 196:1221-1227.

22. Meldrum M. "A calculated risk": the Salk polio vaccine field trials of 1954. BMJ 1998;317:1233-1236.

23. Moore JP, Cao Y, Leu J, et al. Inter- and intraclade neutralization of human immunodeficiency virus type 1: genetic clades do not correspond to neutralization serotypes but partially correspond to gp120 antigenic serotypes. J Virol 1996;70:427-444.

24. Nathanson N. David Bodian's contribution to the development of poliovirus vaccine. AmJ Epidemiol 2005;161: 207-212.

25. Nyambi PN, Nkengasong J, Lewi $\mathrm{P}$, et al. Multivariate analysis of human immunodeficiency virus type 1 neutralization data. J Virol 1996;70:6235-6243.

26. Oyugi JO, Vouriot FC, Alimonti J, et al. A common CD4 gene variant is associated with an increased risk of HIV-1 infection in Kenyan female commercial sex workers. J Infect Dis 2009;199:1327-1334.

27. Putkonen P, Thorstensson R, Ghavamzadeh L, et al. Prevention of HIV-2 and SIVsm infection by passive immunization in cynomolgus monkeys. Nature 1991;352:436438.

28. Qi Q, Liu Y, Cheng Y, et al. Diversity and clonal selection in the human T-cell repertoire. Proc Natl Acad Sci U S A 2014;111:13139-13144.

29. Rencher SD, Slobod KS, Dawson D, et al. Does the key to a successful HIV vaccine lie among the envelope sequences of infected individuals? AIDS Res Hum Retroviruses 1995; 11:1131-1133.

30. Rerks-Ngarm S, Pitisuttithum P, Nitayaphan S, et al. Vaccination with ALVAC and AIDSVAX to prevent HIV-1 infection in Thailand. N Engl J Med 2009;361:2209-2220. 
31. Richman DD, Wrin T, Little SJ, et al. Rapid evolution of the neutralizing antibody response to HIV type 1 infection. Proc Natl Acad Sci U S A 2003;100:4144-4149.

32. Robins HS, Campregher PV, Srivastava SK, et al. Comprehensive assessment of T-cell receptor beta-chain diversity in alphabeta T cells. Blood 2009;114:4099-4107.

33. Ronen K, McCoy CO, Matsen FA, et al. HIV-1 superinfection occurs less frequently than initial infection in a cohort of high-risk Kenyan women. PLoS Pathog 2013;9: e1003593.

34. Ruprecht RM, Ferrantelli F, Kitabwalla M, et al. Antibody protection: passive immunization of neonates against oral AIDS virus challenge. Vaccine 2003;21:3370-3373.

35. Scheid JF, Mouquet H, Feldhahn N, et al. Broad diversity of neutralizing antibodies isolated from memory B cells in HIV-infected individuals. Nature 2009;458:636-640.

36. Sealy R, Chaka W, Surman S, et al. Target peptide sequence within infectious human immunodeficiency virus type 1 does not ensure envelope-specific T-helper cell reactivation: influences of cysteine protease and gamma interferon-induced thiol reductase activities. Clin Vaccine Immunol 2008;15:713-719.

37. Sealy R, Zhan X, Lockey TD, et al. SHIV infection protects against heterologous pathogenic SHIV challenge in macaques: a gold-standard for HIV-1 vaccine development? Curr HIV Res 2009;7:497-503.

38. Sealy RE, Jones BG, Surman SL, et al. Murine monoclonal antibodies for antigenic discrimination of HIV-1 envelope proteins. Viral Immunol 2016;29:64-70.

39. Singh RA, and Barry MA. Generation of multivalent genome-wide $\mathrm{T}$ cell responses in HLA-A*0201 transgenic mice by an HIV-1 expression library immunization (ELI) vaccine. Res Initiat Treat Action 2003;8:17-19.

40. Slobod KS, Coleclough C, Brown SA, et al. Clade, Country and Region-specific HIV-1 Vaccines: are they necessary? AIDS Res Ther 2005;2:3.

41. Smith DJ, Lapedes AS, de Jong JC, et al. Mapping the antigenic and genetic evolution of influenza virus. Science 2004;305:371-376.

42. Smooker PM, Setiady YY, Rainczuk A, et al. Expression library immunization protects mice against a challenge with virulent rodent malaria. Vaccine 2000;18:2533-2540.

43. Stahl-Hennig C, Dittmer U, Nisslein T, et al. Rapid development of vaccine protection in macaques by liveattenuated simian immunodeficiency virus. J GenVirol 1996;77 (Pt 12):2969-2981.

44. Surman S, Lockey TD, Slobod KS, et al. Localization of CD4+ T cell epitope hotspots to exposed strands of HIV envelope glycoprotein suggests structural influences on antigen processing. Proc Natl Acad Sci U S A 2001;98: 4587-4592.

45. Titti F, Sernicola L, Geraci A, et al. Live attenuated simian immunodeficiency virus prevents super-infection by cloned SIVmac251 in cynomolgus monkeys. J Gen Virol 1997;78 (Pt 10):2529-2539.

46. Van Rompay KK, Berardi CJ, Dillard Telm S, et al. Passive immunization of newborn rhesus macaques prevents oral simian immunodeficiency virus infection. J Infect Dis 1998;177:1247-1259.
47. Vesikari T, Wysocki J, Chevallier B, et al. Immunogenicity of the 10-valent pneumococcal non-typeable Haemophilus influenzae protein D conjugate vaccine (PHiD-CV) compared to the licensed 7vCRM vaccine. Pediatr Infect Dis J 2009;28:S66-S76.

48. Weber J, Fenyo EM, Beddows S, et al. Neutralization serotypes of human immunodeficiency virus type 1 field isolates are not predicted by genetic subtype. The WHO Network for HIV Isolation and Characterization. J Virol 1996;70:7827-7832.

49. Wrin T, Crawford L, Sawyer L, et al. Neutralizing antibody responses to autologous and heterologous isolates of human immunodeficiency virus. J Acquir Immune Defic Syndr 1994;7:211-219.

50. Yano M, Gohil S, Coleman JR, et al. Antibodies to Streptococcus pneumoniae capsular polysaccharide enhance pneumococcal quorum sensing. mBio 2011;2. DOI: 10.1128/mBio.00176-11.

51. Yu B, Morales JF, O'Rourke SM, et al. Glycoform and net charge heterogeneity in gp120 immunogens used in HIV vaccine trials. PLoS One 2012;7:e43903.

52. Zhan X, Martin LN, Slobod KS, et al. Multi-envelope HIV1 vaccine devoid of SIV components controls disease in macaques challenged with heterologous pathogenic SHIV. Vaccine 2005;23:5306-5320.

53. Zhan X, Slobod KS, Surman S, et al. Minor components of a multi-envelope HIV vaccine are recognized by typespecific T-helper cells. Vaccine 2004;22:1206-1213.

54. Zinkernagel RM, and Doherty PC. Cytotoxic thymusderived lymphocytes in cerebrospinal fluid of mice with lymphocytic choriomeningitis. J Exp Med 1973;138:12661269.

55. Zinkernagel RM, and Doherty PC. Restriction of in vitro $\mathrm{T}$ cell-mediated cytotoxicity in lymphocytic choriomeningitis within a syngeneic or semiallogeneic system. Nature 1974; 248:701-702.

56. Zinkernagel RM, and Doherty PC. H-2 compatability requirement for T-cell-mediated lysis of target cells infected with lymphocytic choriomeningitis virus. Different cytotoxic T-cell specificities are associated with structures coded for in H-2K or H-2D. J Exp Med 1975;141:1427-1436.

57. Zinkernagel RM, Dunlop MB, Blanden RV, et al. H-2 compatibility requirement for virus-specific T-cellmediated cytolysis. Evaluation of the role of $\mathrm{H}-2 \mathrm{I}$ region and non-H-2 genes in regulating immune response. J Exp Med 1976;144:519-532.

58. Zolla-Pazner S, Gorny MK, Nyambi PN, et al. Immunotyping of human immunodeficiency virus type 1 (HIV): an approach to immunologic classification of HIV. J Virol 1999;73:4042-4051.

Address correspondence to: Dr. Julia L. Hurwitz Department of Infectious Diseases St. Jude Children's Research Hospital 262 Danny Thomas Place Memphis, TN 38105

E-mail: julia.hurwitz@stjude.org 